\title{
Adipocytes, aldosterone and obesity-related hypertension
}

\section{Aurelie Nguyen Dinh Cat, Malou Friederich-Persson, Anna White and Rhian M Touyz}

Institute of Cardiovascular and Medical Sciences, BHF Glasgow Cardiovascular Research Centre, University of Glasgow, Glasgow, UK
Correspondence should be addressed to R M Touyz or A Nguyen Dinh Cat Email

Rhian.Touyz@glasgow.ac.uk or Aurelie.NguyenDinhCat@ glasgow.ac.uk

\begin{abstract}
Understanding the mechanisms linking obesity with hypertension is important in the current obesity epidemic as it may improve therapeutic interventions. Plasma aldosterone levels are positively correlated with body mass index and weight loss in obese patients is reported to be accompanied by decreased aldosterone levels. This suggests a relationship between adipose tissue and the production/secretion of aldosterone. Aldosterone is synthesized principally by the adrenal glands, but its production may be regulated by many factors, including factors secreted by adipocytes. In addition, studies have reported local synthesis of aldosterone in extra-adrenal tissues, including adipose tissue. Experimental studies have highlighted a role for adipocyte-secreted aldosterone in the pathogenesis of obesity-related cardiovascular complications via the mineralocorticoid receptor. This review focuses on how aldosterone secretion may be influenced by adipose tissue and the importance of these mechanisms in the context of obesity-related hypertension.
\end{abstract}

\section{Key Words \\ - aldosterone \\ - synthesis \\ - adipocytes \\ - obesity-related hypertension}

\section{Introduction}

The obesity epidemic threatens to bring with it a significant range of health problems including the increased risk of hypertension and associated cardiovascular disorders. Of note, Brambilla and coworkers found that increased body mass index (BMI) was associated with treatmentresistant hypertension in a group of 1312 European patients with hypertension (Brambilla et al. 2013). Several mechanisms could underlie the development of hypertension in obesity, including direct pressure on the kidney, sympathetic nervous system activity and the over-activation of the renin-angiotensin-aldosterone system (Hall et al. 2015). In this study, we focus on the role of the mineralocorticoid hormone aldosterone in this system and the effects of manipulating this steroid hormone clinically and experimentally in obesity-related hypertension and metabolic conditions.
Emerging evidence implicates the aldosterone in the development of insulin resistance, metabolic syndrome and treatment-resistant hypertension (Vogt et al. 2007, Calhoun \& Sharma 2010). Rising BMI has been shown to positively correlate with increasing plasma aldosterone levels in those with essential hypertension (Rossi et al. 2008) and similarly correlates with waist circumference and blood pressure (Grim et al. 2005, Bochud et al. 2006, Kidambi et al. 2007).

Synthesized in adrenocortical cells of the zona glomerulosa, aldosterone is a blood pressure-regulating hormone completing the well-described reninangiotensin-aldosteronesystem(RAAS). Aldosteroneexerts its physiological effects through the mineralocorticoid receptor (MR). MR is expressed in epithelial tissues such as the renal collecting duct, the colon and sweat glands,

Published by Bioscientifica Ltd 
where activation leads to insertion of transporters which increase sodium and water reabsorption. The receptor is also found in non-epithelial tissues such as the heart (Sainte-Marie et al. 2007), the vasculature (Nguyen Dinh Cat et al. 2010, McCurley et al. 2012) and adipose tissue (Caprio et al. 2007, Nguyen Dinh Cat et al. 2011, Briones et al. 2012). Interestingly, increased MR expression in adipose tissue has been observed in obesity (Hirata et al. 2012, Urbanet et al. 2015). Mice on a high-fat diet not only developed obesity, but also showed increased renal expression of MR protein and its downstream target serumand glucocorticoid-regulated kinase-1 (SGK-1) (Tokuyama et al. 2012). MR binds both aldosterone and glucocorticoids with high affinity. However, glucocorticoids (cortisol for humans, corticosterone for rodents) circulate at 100- to 1000-fold higher concentrations than those of aldosterone $(0.1-1 \mathrm{nM})$. In epithelial tissues, the enzyme 11 beta-hydroxysteroid dehydrogenase type II (11b-HSD2) allows aldosterone to selectively activate MR, by converting cortisol to an inactive metabolite, cortisone (Edwards et al. 1988, Funder 2005, Marzolla et al. 2012).

Adipocytes can synthesize and secrete aldosterone which may exert autocrine and paracrine effects, influencing adipose tissue and local structures such as the vasculature resulting in vascular remodelling (Nguyen Dinh Cat et al. 2011, Briones et al. 2012). In keeping with this effect on the vasculature, MR blockade has been shown to effectively reduce blood pressure in obesityrelated hypertension, and the significant benefits in heart failure are well documented (Pitt et al. 1999, 2003).

\section{Aldosterone production by adrenal glands}

\section{Classical regulators}

Steroid biosynthesis occurs in the adrenal cortex from the precursor cholesterol. Cholesterol is initially converted to pregnenolone by the mitochondrial enzyme P450 scc (side chain cholesterol cleavage) encoded by the gene CYP11A1. The final step is catalyzed by two cytochrome P450 enzymes that display differences in their enzymatic activity, regulation and zonal distribution. 11 $\beta$-hydroxylase (CYP11B1) synthesizes cortisol from 11-deoxyhydrocortisol (DOC) in the zona fasciculata, whereas the aldosterone synthase (CYP11B2) catalyses the conversion of DOC to aldosterone in the zona glomerulosa (Fig. 1A).

With aldosterone's role in the physiology and pathophysiology of the cardiovascular system, it is important to consider the regulation of its biosynthesis and secretion
A

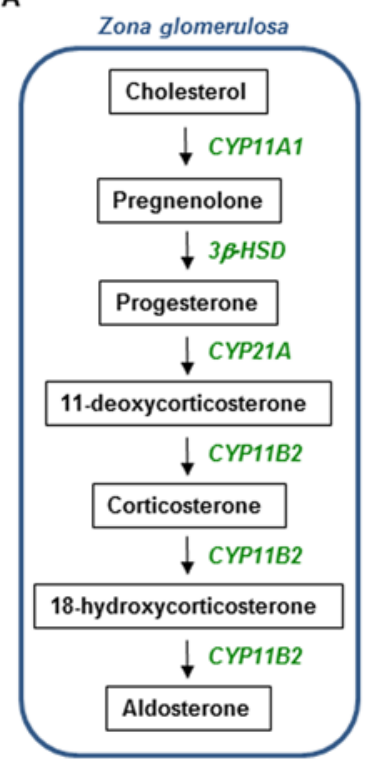

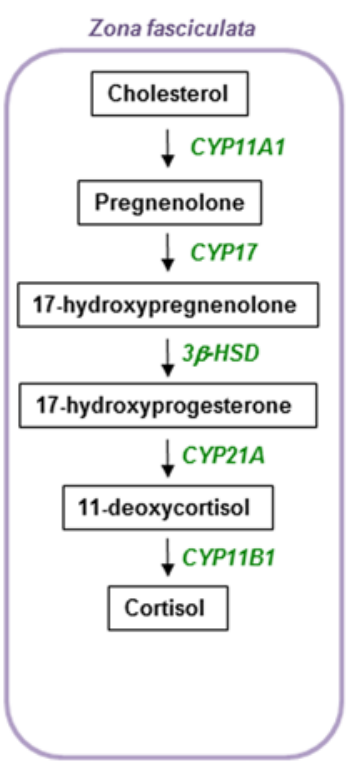

B

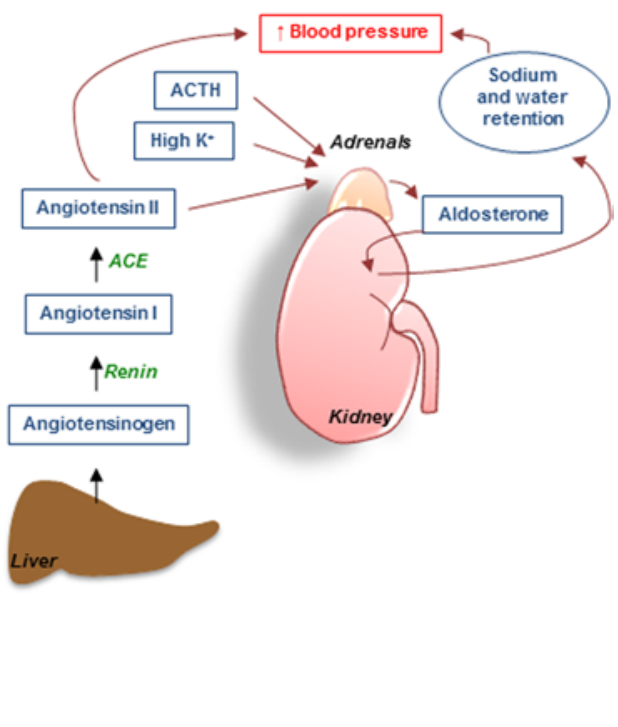

Figure 1

Synthesis of aldosterone and regulators. (A) Synthesis of the mineralocorticoid hormone aldosterone and cortisol from cholesterol. Aldosterone is synthesized in the zona glomerulosa of the adrenal cortex by a series of enzyme steps leading to the conversion of cholesterol to aldosterone. There are two critical enzyme steps: (1) the conversion of cholesterol to pregnenolone cholesterol side-chain cleavage enzyme (CYP11A1) and (2) the conversion of corticosterone to aldosterone by the aldosterone synthase (CYP11B2). However, cortisol is synthesized in the zona fasciculata of the adrenal glands.

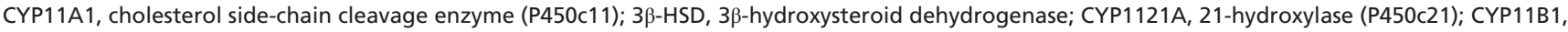
$11 \beta$-hydroxylase; CYP11B2, aldosterone synthase. (B) Main regulators of aldosterone synthesis by the adrenals. A variety of factors modify the aldosterone secretion: the most important are the angiotensin II (Angll) and high concentrations of potassium (K+).

http://jme.endocrinology-journals.org DOI: 10.1530/JME-16-0025
() 2016 Society for Endocrinology Printed in Great Britain
Published by Bioscientifica Ltd 
from the adrenal cortex, especially the signalling pathways involved in the secretory response to the controllers of aldosterone production (Fig. 1B) (Jaisser \& Farman 2016). Angiotensin II (Ang II) and elevated serum potassium $\left(\mathrm{K}^{+}\right)$are the two main regulators of aldosterone production, whereas adrenocorticotrophic hormone (ACTH) and other proopiomelanocortin peptides, sodium, vasopressin, dopamine, atrial natriuretic peptide, beta-adrenergic agents, serotonin and somatostatin are minor modulators (Hattangady et al. 2012, Bollag 2014).

Treatment with Ang II or high levels of $\mathrm{K}^{+}$results in a dose-dependent increase in aldosterone production by human adrenocortical H295R cells (Bird et al. 1993, Rainey et al. 1993). These agents have parallel effects on CYP11B2 mRNA levels, whereas activation of the protein kinase A (PKA) pathway by cAMP analogues preferentially increases CYP11B1 mRNA (Bird et al. 1995, Denner et al. 1996, Bassett et al. 2000). Ang II binds to G-protein-coupled receptors, activating phospholipase $\mathrm{C}$ which hydrolyzes PIP2 to IP3, increasing intracellular calcium $\left(\mathrm{Ca}^{2+}\right)$ ions which activates $\mathrm{Ca}^{2+}$-calmodulin-dependent protein kinase (CaMK), and diacylglycerol-dependent protein kinase C (Hu et al. 2012, Felizola et al. 2014). ACTH, however, binds to the cell-surface melanocortin-2 receptor, which activates adenylate cyclase, produces cAMP and activates downstream PKA (Bassett et al. 2004). It is possible that these pathways have different efficiencies - perhaps the Ang II-mediated G-protein signalling pathway is simply better at increasing production of the necessary enzymes. The principle action of ACTH is in the zona fasciculata of the adrenal cortex where it stimulates the PKA-mediated phosphorylation of steroidogenic proteins, including the rate-limiting steroidogenic acute regulatory (STAR) protein (Arakane et al. 1997), which promotes the transport of cholesterol into the mitochondria (Lin et al. 1995), where a number of enzymatic reactions lead to terminal glucocorticoid synthesis (cortisol in humans, corticosterone in rodents). By stimulating $\mathrm{K}^{+}$excretion, aldosterone constitutes a negative feedback loop.

\section{Adipocyte-derived factors}

Approaches using adipose tissue-conditioned media to determine its effects on adrenocortical cell lines show increased steroidogenesis, both in murine and cellular models, following exposure to conditioned media (Ehrhart-Bornstein et al. 2003, Nagase et al. 2006, Krug et al. 2007). These studies suggest that the adipose tissue secretome contains 'mineralocorticoid-releasing-factors' that stimulate aldosterone synthesis in adrenocortical cells including aldosterone production which is increased in obese spontaneously hypertensive rats (Nagase et al. 2006). This further suggests a direct link with cardiovascular pathologies (Ehrhart-Bornstein et al. 2003, Krug \& Ehrhart-Bornstein 2008).

Adipocyte-derived factors are proposed to mediate their effects through the canonical Wnt-signalling pathway (Schinner et al. 2007) and ERK1/2 mitogen-activated protein kinase (MAPK) signalling, resulting in increased STAR expression and sensitization to Ang II stimulus. However, this effect is not critically dependent on Angiotensin II via its receptor type $1\left(\mathrm{AT}_{1} \mathrm{R}\right)$ (Krug et al. 2007). As adipocytes are also located within the adrenal glands, the factors they release may influence adrenals in a paracrine manner (Ehrhart-Bornstein et al. 2003). We describe three wellcharacterized adipocyte-derived factors that influence adrenal aldosterone secretion: leptin, adiponectin and complement-C1q TNF-related protein-1 (CTRP-1) (Fig. 2).
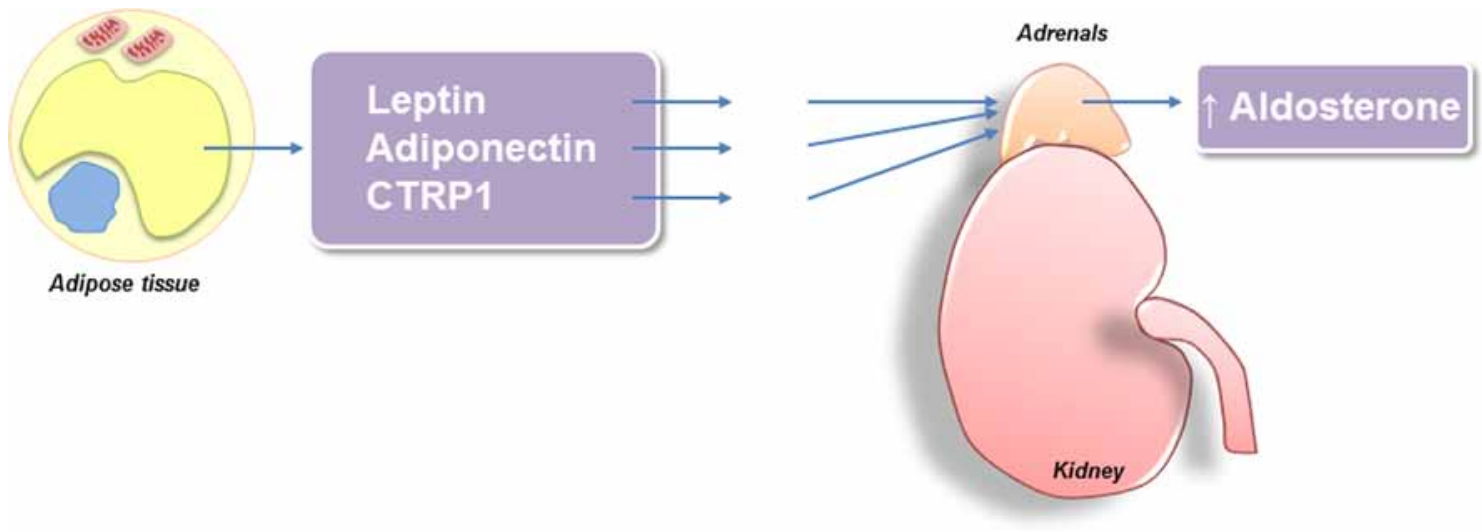

Figure 2

Novel regulators of aldosterone production in adrenals. New regulators of the secretion of aldosterone by the adrenal glands have been identified such as leptin, adiponectin and complement-C1q TNF-related protein-1 (CTRP1). 
Leptin Leptin, known as the 'satiety hormone', is a $16 \mathrm{kDa}$ protein encoded by $\mathrm{Ob}$ gene and secreted mainly from white adipose tissue; it can be secreted in lower levels from other tissues, such as mammary gland, stomach, muscle, bone marrow, placental and fetal tissues (Friedman 2014, Park \& Ahima 2015). Leptin receptors are highly expressed in the hypothalamus where they are required for the regulation of appetite, energy expenditure, body weight, thermogenesis, fertility and immune function (Ahima et al. 1996, Wada et al. 2014, Freitas Lima et al. 2015, Park et al. 2015). Downstream signalling in the central nervous system and peripheral tissues includes Janus-activated kinase/signal transducer and activator of transcription (Jak/STAT), insulin receptor substrate (IRS)/phosphatidylinositol 3 kinase (PI3K), SH2containing protein tyrosine phosphatase 2 (SHP2)/MAPK and 5'-adenosine monophosphate-activated protein kinase (AMPK)/acetyl-CoA carboxylase (ACC) (Yang et al. 2007, Park \& Ahima 2014). Interestingly, serum leptin levels are significantly elevated in most obese individuals and correlate with BMI (Mantzoros 1999, Ahima 2008). Numerous investigations ranging from clinical and animal model studies to in vitro analyses implicate leptin in the pathogenesis of obesity-related cardiovascular diseases (Sweeney 2010, Hou \& Luo 2011). Obese individuals can develop 'leptin resistance' where they become insensitive to the metabolic effects of leptin, but not to effects on the cardiovascular system (Pan et al. 2014, Balland \& Cowley 2015, Sáinz et al. 2015). In a recent study, Huby and coworkers investigated whether leptin directly regulates aldosterone secretion by adrenals and whether this leptinmediated aldosterone production impairs cardiovascular function (Huby et al. 2015). They showed that the leptin receptor and CYP11B2 are co-expressed in human and rats adrenal zona glomerulosa cells. They demonstrated that a) genetic reduction or increase in leptin signalling, respectively, prevents or enhances adrenal CYP11B2 expression and aldosterone release; b) endogenous and exogenous leptin directly activates CYP11B2, resulting in increased production of aldosterone via $\mathrm{Ca}^{2+}$-dependent mechanisms. This is independent of the renin-angiotensin and sympathetic nervous systems. Moreover, the authors demonstrated MR-dependent induction of endothelial dysfunction by leptin which was associated with increased levels of cardiac pro-fibrotic markers (Huby et al. 2015).

Adiponectin Adiponectin is a specific adipocyte-secreted protein that is metabolically active and anti-inflammatory (Sowers 2009, Nigro et al. 2014). Adiponectin can improve insulin sensitivity and is inversely associated with obesity and insulin resistance, two common comorbidities in cardiovascular disease (Antoniades et al. 2009, Shibata et al. 2012, Nigro et al. 2014, Antonopoulos et al. 2015). Adiponectin receptors are present in human and mouse adrenal glands (Rossi et al. 2006, Li et al. 2009). In the murine adrenocortical Y1 cell line, adiponectin decreased steroidogenesis enzymes resulting in decreased aldosterone and corticosterone production (Li et al. 2009). However, in primary cultured rat adrenal cells, adiponectin increased steroidogenesis (Paschke et al. 2010). Additionally, in cultured human adrenocortical cells, adiponectin increased STAR expression and cortisol production, a process dependent on AMPK, Akt and ERK1/2 signalling. This may be an important regulatory system given that glucocorticoids are reported to decrease adiponectin secretion by adipocytes (Degawa-Yamauchi et al. 2005, Iwen et al. 2008). Levels of adiponectin are decreased in obese $d b / d b$ mice and this is prevented by MR antagonism (Guo et al. 2008).

CTRP-1 Complement-C1q TNF-related protein-1 (CTRP-1) is an adiponectin paralogue with 30-50\% shared sequence homology and may share some of adiponectin's biochemical properties. CTRP-1 is primarily and highly expressed from cells in the stromal vascular fraction of adipose tissue and is also specifically expressed in the zona glomerulosa of murine and human adrenal cortex and in vascular wall tissue (Wong et al. 2008). Jeon and coworkers demonstrated that CTRP-1 regulates adrenal aldosterone production through increases in intracellular $\mathrm{Ca}^{2+}$ levels and induction of CYP11B2 expression (Jeon et al. 2008). Moreover, CTRP1 did not increase the transcription of CYP11B1, the enzyme responsible for glucocorticoid synthesis. Previous reports found that Ang II increased the transcription of CYP11B1 and STAR (Li et al. 2003, Romero et al. 2004), and $\mathrm{AT}_{1} \mathrm{R}$ blockade had no effect, suggesting that this aldosterone secretion induced by CTRP-1 is independent of Ang II-mediated regulation mechanism (Jeon et al. 2008).

Most data indicate that CTRP-1 is increased in obesity, although conflicting results exist. Kim and coworkers showed increased CTRP-1 levels in obese $d b / d b$ mice and Zucker fatty rats (Kim et al. 2006). However, Peterson's group reported decreased levels of CTRP-1 in diet-induced obese mice, and that transgenic CTRP1 overexpressing mice are protected from obesity through increased AMPK activation and subsequent increased fatty acid oxidation and energy expenditure (Peterson et al. 2012). In addition, CTRP-1 levels were increased http://jme.endocrinology-journals.org DOI: 10.1530/JME-16-0025
() 2016 Society for Endocrinology Printed in Great Britain
Published by Bioscientifica Ltd 
in adiponectin-null mice (Peterson et al. 2012). Kim and coworkers reported a specific relationship between inflamed adipose tissue, stromal vascular fraction and CTRP-1, suggesting that the dysregulation of CTRP-1 levels in obesity is strongly associated with chronic inflammation in adipose tissue (Kim et al. 2006).

Additionally, patients with metabolic syndrome and type 2 diabetes have increased circulating levels of CTRP-1 compared with healthy individuals. This is positively correlated with BMI, fasting glucose, TNF- $\alpha$ (tumour necrosis factor-alpha) and HBA1c (glycated haemoglobin A1c) (Chalupova et al. 2013, Xin et al. 2014). Circulating levels of CTRP-1 are also increased in non-obese hypertensive patients; hence, CTRP-1 has been suggested as a critical protein associated with the pathophysiology of obesity-related hypertension (Jeon et al. 2008).

\section{Non-adrenal production of aldosterone}

\section{Cardiovascular and central nervous systems}

Extra-adrenal aldosterone production may represent important local regulatory mechanisms in tissues reliant on a dynamic vascular supply. In the cardiovascular system, the machinery for aldosterone production is found both in endothelial and smooth muscle cells (Takeda et al. 1995, Hatakeyama et al. 1996, Takeda et al. 1996). Transcripts of $C y b 11 b 2$ are increased in aortas from spontaneously hypertensive rats (Wu et al. 1998), and isolated rat mesenteric arteries produce aldosterone (Takeda et al. 1995). Key steroidogenesis enzymes, including the terminal enzymes for corticosterone and aldosterone synthesis, are also expressed in the rat heart (Silvestre et al. 1998). Interestingly, aldosterone levels in the rat heart are approximately 17 -fold higher than in plasma, possibly owing to a slower degradation rate (Delcayre \& Silvestre 1999). In the central nervous system, neurosteroids were first established in 1987 when P450scc was found to be expressed in white matter (Le Goascogne et al. 1987) and other cells of the brain including neurons and glial cells (Zwain \& Yen 1999, Kushida \& Tamura 2009). Star is highly expressed throughout the brain with maximal levels in the cerebellum (Furukawa et al. 1998), and both Cyb11b1 and $C y b 11 b 2$ are expressed in the brain (Strömstedt \& Waterman 1995, Gomez-Sanchez et al. 1996, 1997).

\section{Adipose tissue}

Machinery for aldosterone synthesis and MR expression Included in the several hundred factors produced by adipocytes are components of the reninangiotensin system (Thatcher et al. 2009). Along with the expression of NR3C2 (MR) and NR3C1 (GR) in adipocytes (Caprio et al. 2007, 2011, Campbell et al. 2011), the necessary components for endogenous aldosterone production are present in rodent and human adipocytes (Nguyen Dinh Cat et al. 2011, Briones et al. 2012). Briones and coworkers demonstrated adipocyte secretion of aldosterone which was increased in obese animals and upon stimulation with Ang II. This adipocyte-derived aldosterone may in turn impact on adipocyte biology by regulating adipogenesis, but also on vascular function in an MR-dependent manner (Briones et al. 2012). Mechanisms of regulation of aldosterone production by adipocytes include both calcineurin/nuclear factor of activated T (NFAT) cells signalling pathways (Briones et al. 2012) and ROS-dependent pathways (Rios et al. 2015). Recently, the role of adipocyte-derived aldosterone was also implicated in renal disease. In fifth/sixth nephrectomized rats (a model of chronic renal failure) and in patients with chronic kidney disease (CKD), plasma levels of aldosterone and CYP11B2 expression in adipose tissue are increased, as well as MR nuclear expression and its downstream signalling targets (Hosoya et al. 2015). Treatment with MR antagonist spironolactone ameliorated insulin resistance in patients with $\mathrm{CKD}$, and partially reversed impaired glucose tolerance in nephrectomized rats. It was suggested that adipocyte-derived aldosterone production may be contributing to the pathogenesis of insulin resistance in patients with CKD (Tirosh et al. 2010, Hosoya et al. 2015). In our studies, the ratio between adrenal- and adipocyte-derived aldosterone in mouse and humans for the levels of the aldosterone synthase is four times (Briones et al. 2012). Thus, the relative significance of this adipocyte-derived aldosterone compared with that of the zona glomerulosa remains an interesting question to elucidate. We demonstrated that this adipocyte aldosterone affects vascular signalling such as pro-fibrotic and pro-inflammatory signalling pathways (Nguyen Dinh Cat et al. 2011). Presumably, the actions of adipocyte aldosterone contribute to the effects of circulating levels of aldosterone.

\section{Regulators of adipocyte aldosterone production}

Ang II/calcineurin-NFAT Based on the work from Yamashiro and coworkers that reported regulation of CYP11B2 and aldosterone production via calcineurin-dependent pathway in adrenocortical cells (Yamashiro et al. 2010), Briones and coworkers also showed involvement of

Published by Bioscientifica Ltd. 
this pathway in adipocyte-derived aldosterone. In differentiated 3T3-L1 adipocytes, Ang II/AT ${ }_{1} \mathrm{R}$ regulates Cyb11b2 expression and adipocyte-secreted aldosterone in a calcineurin/NFAT-dependent manner, an effect blocked by FAD286 (selective CYP11B2 inhibitor). Indeed, calcineurin inhibitors (cyclosporin A and FK506) and the specific NFAT inhibitor (VIVIT) abrogated Ang II-induced aldosterone secretion by adipocytes. In addition, Ang II stimulated NFAT nuclear translocation, an effect blocked by $\mathrm{AT}_{1} \mathrm{R}$ blocker candesartan, and decreased NFATc4 phosphorylation, which was restored by cyclosporin A and FK506 (Briones et al. 2012) (Fig. 3A).

CETP inhibitors Cholesteryl ester-transfer protein (CETP) inhibitors increase the levels of high-density lipoprotein. Clinical trials of the CETP inhibitors torcetrapib (Barter et al. 2007) and dalcetrapib (Schwartz et al. 2012) revealed hyperaldosteronism and hypertension as clinically relevant adverse effects. Rios and coworkers showed that in a human adipocyte model, CETP inhibitors increased CYP11B2, CYP11B1 and STAR expression. In adipocytes, this was associated with an increase in ROS generation and activation of peroxisome proliferation-activated receptorgamma (PPAR-G) and signal transducer and activator of transcription 3 (STAT3) (Rios et al. 2015) (Fig. 3B). This regulation of aldosterone production in adipocytes sheds light on the close relationship between hypertension and hyperaldosteronism. The precise contribution of adipocyte-derived aldosterone remains to be determined; however, the adverse effects observed with CETP inhibitors infer a greater systemic role than currently accepted.

Reactive oxygen species Rajamohan and coworkers demonstrated that ROS are key regulators of aldosterone production in adrenal glands. In human and rat adrenocortical cells, Ang II increased ROS levels through upregulation of NADPH oxidase (Nox) 1, 2 and 4 and ultimately resulted in increased CYP11B2 levels and aldosterone production. Importantly, this process was blocked or attenuated by not only an $\mathrm{AT}_{1} \mathrm{R}$ antagonist but also antioxidants, pharmacological Nox inhibition and siRNA-mediated Nox silencing. Similarly, exogenous
A

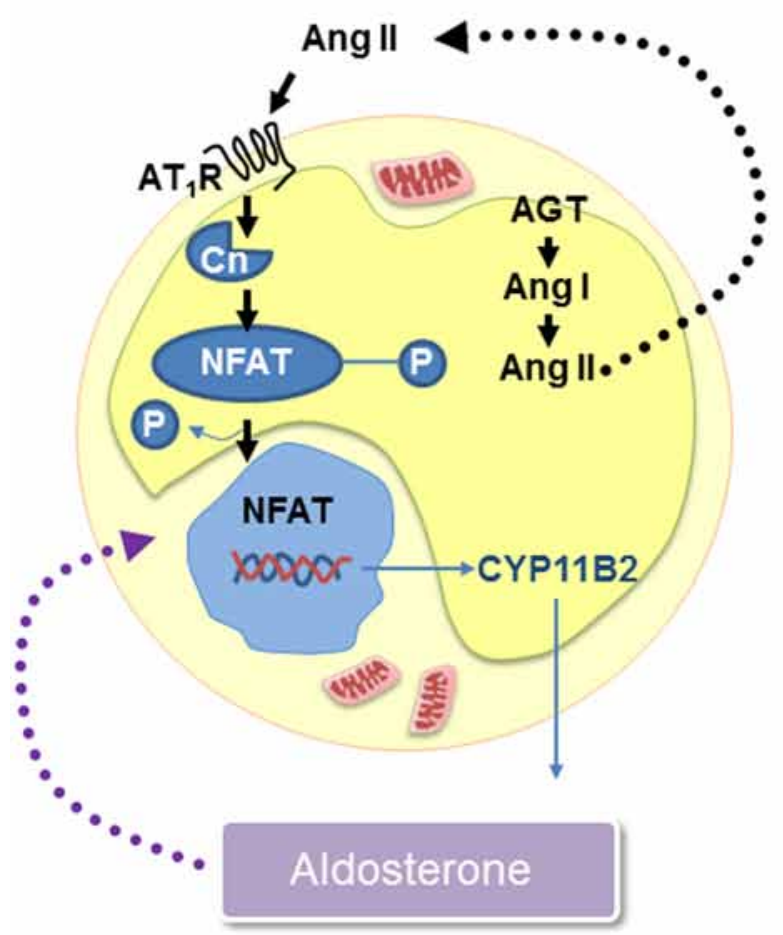

B

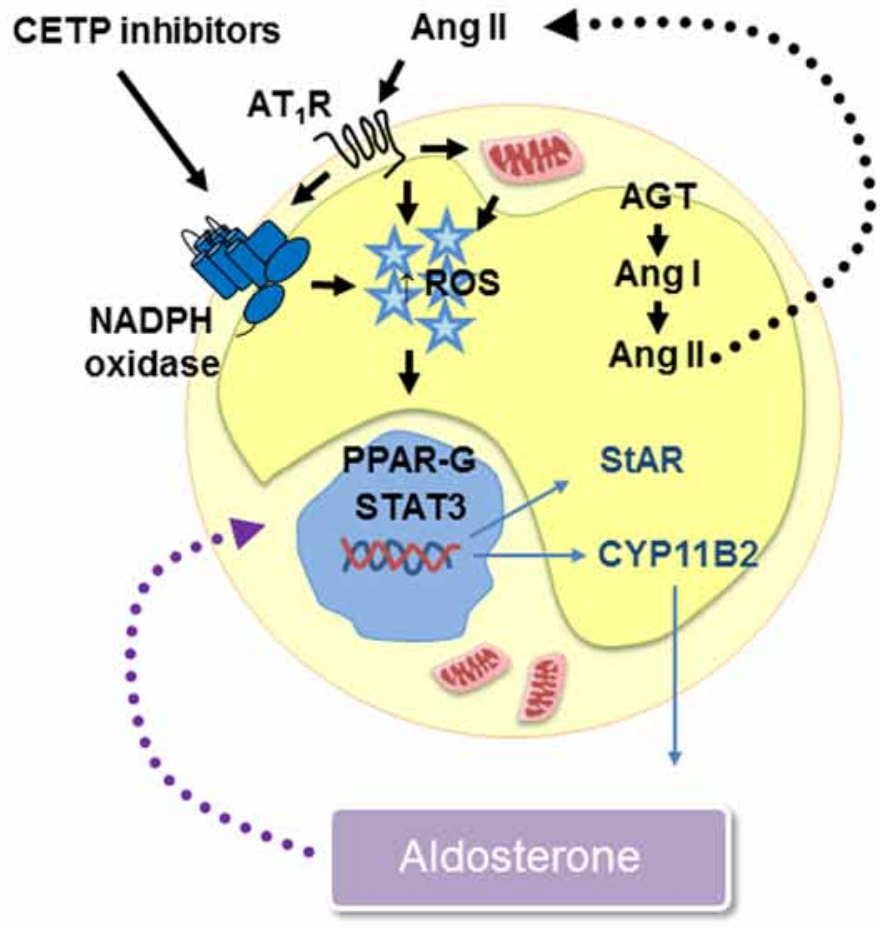

Figure 3

Regulation of aldosterone production in adipocytes. (A) Angiotensin II via its receptor type $1\left(\mathrm{AT}{ }_{1} \mathrm{R}\right)$ regulates the aldosterone synthase (CYP11B2) expression and the adipocyte-secreted aldosterone in a calcineurin/nuclear factor of activated T (NFAT)-dependent manner. (B) Cholesteryl ester-transfer protein (CETP) inhibitors regulates the aldosterone synthase (CYP11B2) expression through increase in ROS generation and activation of peroxisome proliferation-activated receptor-gamma (PPAR-G) and signal transducer and activator of transcription 3 (STAT3). AGT, angiotensinogen; Ang, angiotensin; ROS, reactive oxygen species; STAR, steroidogenic acute regulatory protein.

http://jme.endocrinology-journals.org DOI: 10.1530/JME-16-0025
() 2016 Society for Endocrinology Printed in Great Britain
Published by Bioscientifica Ltd 
hydrogen peroxide can increase CYP11B2 activity, leading to increased aldosterone production by adrenocortical cells (Rajamohan et al. 2012). Several reports show increased ROS levels in adipose tissue from obese and/or hypertensive animals (Furukawa et al. 2004), raising the possibility of adipose tissue-derived ROS as the molecular connection between increased aldosterone levels and obesity-related hypertension. However, caloric restriction and exercise can improve the state of oxidative stress (Imayama et al. 2012). Nonetheless, a cause and effect relationship between oxidative stress and obesity is not well understood. Adipose tissue from obese $d b / d b$ mice showed oxidative stress, increase in $C y b 11 b 2$ expression, resulting in aldosterone production by mature adipocytes (unpublished observations). The Nox1/4-inhibiting compound GKT137831 decreased Cyb11b2 mRNA levels and adipocyte-derived aldosterone production in obese $d b / d b$ mice suggesting that oxidative stress does contribute to the pathogenesis of obesity.

AMPK activators In a published abstract, White and coworkers demonstrated that pharmacological activators of AMPK increase aldosterone secretion from cultured adipocyte models. In the murine adipocyte cell line 3T3-L1, the AMPK activator 5-aminoimidazole4-carboxamide ribonucleotide (AICAR) increased aldosterone secretion into culture medium. Similarly, in the human adipocyte cell line SW872, the specific AMPK activator A769662 increased the aldosterone secretion along with STAR expression. However, when SW872 cells were treated with the diabetes drug and non-specific AMPK activator metformin, aldosterone secretion was not changed (White, personal communication). AMPK is a key energy regulator activated in low-energy states and is known to stimulate mitochondrial biosynthesis (Marcinko et al. 2014). Although the effect described here was initially unexpected, the author suggests it may be reasoned by a direct effect on mitochondrial number and therefore steroid production. Alternatively, this effect may represent a mechanism in the autoregulation of adipose tissue perfusion during starvation, when adipocyte-secreted vasoactive factors may be required without influencing systemic blood pressure. Considering that AMPK activity is reduced in adipose tissue of insulin-resistant obese patients undergoing bariatric surgery (Gauthier et al. 2011), it is likely that this mechanism may not be relevant in such individuals and therefore may represent a dynamic physiological rather than chronic pathophysiological regulation of adipocyte aldosterone secretion. One study assessed the effect of AICAR on adrenal steroidogenesis focussing on androgen production. Here, AICAR activated AMPK in human adrenocortical cells (H295R) and increased the activity of CYP17A1-17,20 lyase to facilitate androgen production. The authors did not investigate the effects on aldosterone production (Hirsch et al. 2012). As discussed in the 'Adipocyte-derived factors' section adiponectin, which signals via AMPK, was found to have different effects on steroidogenesis in cultured adrenal cell lines from different species including increased STAR expression and cortisol secretion in H295R cells. In addition, adiponectin increased ACTH secretion from the mouse AtT20 pituitary cell line and rat primary pituitary cells, suggesting influence over steroidogenesis at different stages of the hypothalamicpituitary-adrenal axis (Chen et al. 2014). It would be of interest to define the effect of adiponectin on adipocyte aldosterone production and to further examine the AMPK dependence of such effects.

Role of MR activation in adipose tissue Despite its key role in renal sodium reabsorption and blood pressure control, MR activation regulates important physiological functions in adipose tissue including differentiation of preadipocytes into matures adipocytes (Caprio et al. 2007, 2011) and promotion of adipose tissue inflammation via induction of cytokines (adipokines) including TNF- $\alpha$, monocyte chemotactic protein-1 (MCP-1) and IL-6 in white adipose tissue, while decreasing the thermogenic activity and lowering uncoupling protein-1 (UCP-1) transcription of brown adipose tissue (Zennaro et al. 2009, Kargi et al. 2014). Interestingly, MR mRNA expression positively correlates with increasing BMI in humans and is increased in obese $d b / d b$ mice (Hirata et al. 2012, Urbanet et al. 2015). This suggests that MR over-activation in adipose tissue triggers deleterious effects within the adipose tissue; in particular, it contributes to insulin resistance and oxidative stress and to the development of obesity-associated cardiovascular complications (Sowers et al. 2009). Our group recently demonstrated that adipocyte-specific MR over-activation in mice leads to insulin resistance, visceral obesity and dyslipidaemia (Urbanet et al. 2015), as well as vascular dysfunction through redox-sensitive-dependent mechanisms (Nguyen Dinh Cat et al. 2016). Adipose tissues from these transgenic mice displayed increased levels of ROS, markers of macrophages and pro-inflammatory cytokines, including IL-6, MCP-1 and RANTES (regulated on
○ 2016 Society for Endocrinology Printed in Great Britain
Published by Bioscientifica Ltd 
activation, normal $\mathrm{T}$ cell expressed and secreted) versus controls. In our conditional transgenic mouse model over-expressing MR in adipocytes, we do not know whether aldosterone or glucocorticoid activates MR in adipose tissue. This question remains under debate as reports showed that adipocytes do not have significant 11b-HSD2 activity and yet maintain a relatively high level of 11b-HSD1 activity, allowing glucocorticoids to be the main ligand for adipocyte-MR (Kargi et al. 2014). Moreover, visceral obesity and metabolic syndrome have been associated with increased adipose 11b-HSD1 activity, further increasing intra-adipocyte cortisol concentrations (Morton et al. 2004, Koska et al. 2006, Stimson \& Walker 2007).

\section{Aldosterone: clinical implications and targets}

\section{Obesity-related hypertension}

Knowing that adipocytes can regulate both local adipose and adrenal aldosterone secretion, it is tempting to conclude that adipocytes are responsible for elevations in blood pressure in obesity. Primary hyperaldosteronism, due to either a unilateral adrenal adenoma or bilateral gland hyperplasia, is associated with insulin resistance in obese hypertensive patients (Catena et al. 2006, Garg et al. 2010), and such metabolic complications appear to be directly related to aldosterone as they are corrected by either adrenalectomy or MR antagonist. Aldosterone production is increased in normotensive overweight subjects and has a weak correlation with insulin resistance measured by homeostatic model assessment (HOMA-IR) (Bentley-Lewis et al. 2007). Obesity-associated inflammation contributes to the development of insulin resistance. Aldosterone has direct effects within adipose tissue including inducing insulin resistance and inflammation, again suggesting that aldosterone might be a link between obesity, insulin resistance and inflammation (Gilbert \& Brown 2010, Tirosh et al. 2010, Bruder-Nascimento et al. 2014). Furthermore, in 3T3-L1 adipocytes, aldosterone was reported to degrade IRS-1 and IRS-2 via GR-mediated increased ROS which was associated with increased phosphorylation of nuclear factor kappa B (Wada et al. 2009). There is much interest in the mechanisms of aldosterone signalling in adipose tissue and it has been questioned whether there is an as yet undiscovered mechanism by which it mediates non-genomic effects (Nguyen Dinh Cat \& Jaisser 2012).
As there is a wealth of evidence implicating aldosterone in the pathogenic mechanisms of obesity-related hypertension, it is of significant interest to consider the benefits of manipulation of this system and when this should be considered during the course of treatment.

\section{Inhibitors of aldosterone synthesis and MR-activity Spironolactone and eplerenone}

Spironolactone Spironolactone is a non-selective MR antagonist which also antagonizes androgen and progesterone. In the UK, it is recommended for use in treatment-resistant hypertension, but is not licensed for this indication (NICE guidelines CG127 2011). It is used widely to treat heart failure and there is a wealth of evidence demonstrating its mortality benefits in this condition most notably from the landmark RALES study (Pitt et al. 1999). Unfortunately, it has some intolerable side effects due to the non-selective nature of its action, most frequently gynaecomastia which affected $10 \%$ of men in the RALES study (Pitt et al. 1999).

The potential benefits of spironolactone in metabolic conditions such as obesity-related hypertension are of interest and the literature to date is largely supportive of a beneficial role. In a group of obese hypertensive individuals treated with an ACE inhibitor with or without spironolactone, spironolactone was found to have greater benefits in blood pressure and urine albumin excretion (Bomback et al. 2009). Spironolactone improved LV function and decreased circulating pro-collagen levels in obese patients with impaired LV diastolic function (measured by mitral annular velocity) (Kosmala et al. 2013). Moreover, spironolactone may influence adipokine secretion such as adiponectin, which is normally decreased in obesity. In individuals with poorly controlled diabetes, spironolactone increased circulating levels of adiponectin but not in those with adequate glycaemic control (Matsumoto et al. 2006). Another study looking at the metabolic condition polycystic ovary syndrome found that spironolactone was beneficial in obese subjects who after 1 year had improved insulin sensitivity measured by homeostatic model assessment of insulin resistance (HOMA-IR) and decreased triglycerides (Zulian et al. 2005). Experimental studies have shown that MR, rather than the GR, is required for normal steroid-induced adipogenesis (Caprio et al. 2007). The same group has also shown that MR antagonism in vivo and in vitro can lead to browning of white adipocytes demonstrated by increased UCP-1 expression (Armani et al. 2014).

Published by Bioscientifica Ltd. 
Eplerenone Eplerenone, a more selective MR antagonist, also benefits patients with heart failure (Zannad et al. 2011) and interestingly has additional benefits in those with diabetes following myocardial infarction compared with those without diabetes (O'Keefe et al. 2008). A substudy of the EMPHASIS trial examined diabetes risk, and found no difference in the incidence of type 2 diabetes in heart failure patients with or without eplerenone treatment (Preiss et al. 2012). In studies assessing endothelial function, eplerenone improved brachial artery flowmediated dilatation in subjects with increased BMI (Hwang et al. 2013), and in C57BL/6 mice on high-fat diet, eplerenone attenuated impaired endothelium-dependent acetylcholine-induced vasorelaxation of aortic rings (Schäfer et al. 2013). Further evidence from preclinical studies supports a metabolic benefit of eplerenone. In a canine study, eplerenone attenuated high-fat-dietinduced increases in weight and blood pressure further implicating aldosterone or at least the MR in obesityrelated hypertension (de Paula et al. 2004). Hirata and coworkers showed that eplerenone reduces insulin resistance and macrophage infiltration in adipose in $d b /$ $d b$ and $o b / o b$ mouse models of obesity (Hirata et al. 2009).

However, in C57/B16 mice on a 60\% high-fat diet for 20 weeks with or without eplerenone or adrenalectomy, serum aldosterone was highest in the group receiving eplerenone and was unaffected by high-fat diet alone. Eplerenone did not affect diet-induced weight gain or fatty liver but did prevent blood pressure elevation and attenuated diet-induced rises in serum insulin and HOMA-IR (Gamliel-Lazarovich et al. 2013). Another study that treated obese $d b / d b$ mice from 8 to 25 weeks of age with eplerenone also showed no change in weight, but there was a prevention of pro-inflammatory gene expression in retroperitoneal adipose tissue (Guo et al. 2008).

Inhibitors of regulators of aldosterone secretion Targeting the production of aldosterone to benefit cardiometabolic disorders associated with highfat diet is intriguing given the benefits of MR antagonism. There is certainly evidence of increased circulating aldosterone in obese individuals, and this has been mimicked in rodents upon high-fat diet resulting in both increased circulating aldosterone and gene expression of CYP11B2 in the adrenal glands (Northcott et al. 2012).

The metabolic functions of this enzyme have been interrogated using a transgenic aldosterone synthase knockout mouse model; these animals were less prone to the elevated glucose, adipose tissue macrophage infiltration and hepatic steatosis associated with a 12-week highfat diet. However, weight gain was unchanged and fasting insulin was highest in the aldosterone synthase knockout mice on the high-fat diet (Luo et al. 2013). This suggests involvement of aldosterone in some but not all of the adipose tissue dysfunction related to insulin resistance associated with obesity.

Driven by interest in this field, two novel drugs have been developed to inhibit aldosterone synthase, FAD286 and LCI699, which have been used in a number of studies evaluating their benefits. From a clinical perspective, these have ultimately been limited by the lack of specificity for aldosterone synthase (CYP11B2) compared with 11ß-hydroxylase (CYP11B1). However, there is now evidence of benefit in Cushing's syndrome and clinical trials are ongoing in this area. Studies outlining the existing evidence of these agents have been thoroughly reviewed by Hargovan and Ferro (Hargovan \& Ferro 2014).

Preclinical studies of FAD286 have focused on hypertension and heart failure models. For example, FAD286 was found to significantly inhibit the renin-angiotensinaldosterone system-mediated cardiac fibrosis and hypertension in a transgenic mouse model overexpressing human renin and angiotensinogen, although to a lesser extent than the $\mathrm{AT}_{1} \mathrm{R}$ blocker, losartan (Fiebeler et al. 2005). In addition, spontaneous hypertensive rats treated with FAD286 and spironolactone displayed severe dehydration and hyperkalaemia (Menard \& Pascoe 2006). Another feature of aldosterone synthase inhibition is the increase of precursors such as deoxyhydrocorticosterone/deoxyhydrocortisol (DOC) which may have independent clinical effects.

Although designed to be more aldosterone synthasespecific than FAD286, LCI699 was also shown to alter cortisol synthesis and hypothalamic-pituitary-adrenal function. Despite this, a number of trials have been published relating to aldosterone dynamics including phase 1 and 2 studies which found a significant reduction in circulating aldosterone (Amar et al. 2010, Rossignol et al. 2011). Additionally, LCI699 has been compared with eplerenone in blood pressure regulation in two studies; one showed similar blood pressure improvements compared with eplerenone (Calhoun et al. 2011), whereas the other showed no blood pressure reduction despite lowering aldosterone levels (Karns et al. 2013).

It must be recognized that aldosterone is not the only ligand for MR and cortisol may mediate a proportion of the metabolic effects mediated via MR, particularly in adipose http://jme.endocrinology-journals.org DOI: 10.1530/JME-16-0025
() 2016 Society for Endocrinology Printed in Great Britain
Published by Bioscientifica Ltd 


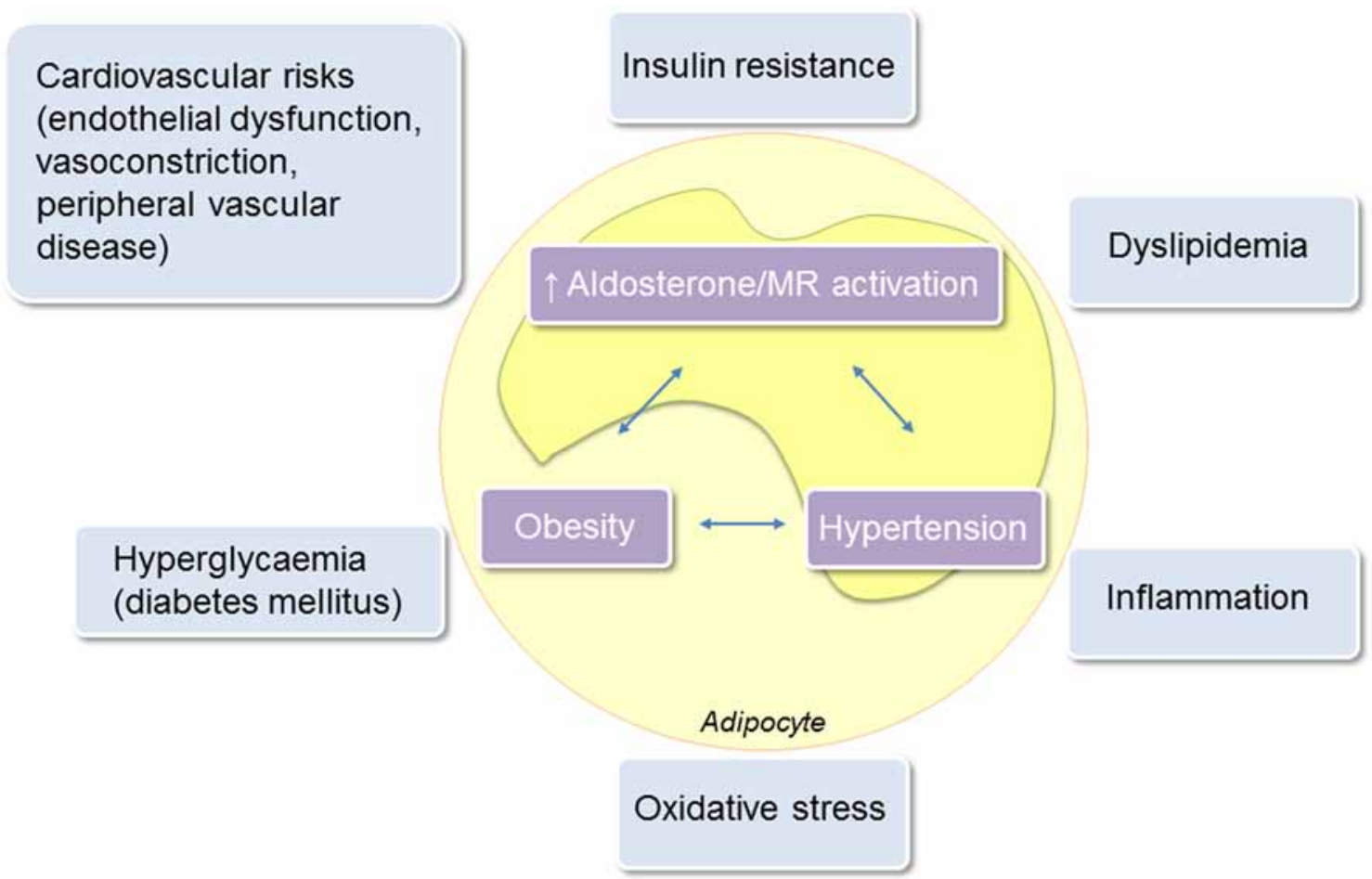

Figure 4

Summary of the pathophysiological roles of adipose aldosterone/MR activation in obesity-related hypertension.

tissue which lacks the cortisol converting enzyme 11-beta hydroxysteroid dehydrogenase. Indeed, recent evidence demonstrates that cortisol is co-secreted in around 10\% of cases of primary hyperaldosteronism (Spath et al. 2011, Fujimoto et al. 2013).

Modulation of adipokines Knowing that adipokines can modulate aldosterone secretion, we consider that modulation of adipokines, through weight loss, exercise or medication, may be directly responsible for decreasing aldosterone and perhaps this is an area for therapeutic manipulation. If we consider leptin, which has been shown to increase aldosterone secretion, it may be that this is an important mechanism in obesity-related hypertension. However, this concept is complicated by the common coexistence of leptin resistance in obesity (Crujeiras et al. 2015) and that in the $d b / d b$ mouse model, where there is a point mutation of the leptin receptor, aldosterone levels are elevated (Briones et al. 2012). Inhibiting leptin would therefore not seem a viable target for the manipulation of this system. Further identification of possible targets or adipokines involved in aldosterone secretion would therefore be useful.

\section{Summary and conclusion}

Understanding the mechanisms linking obesity with hypertension is important in the current obesity and hypertension epidemic and might have implications for the management of hypertension in overweight and obese patients. We have outlined some mechanisms whereby adipocytes may influence tissue and systemic aldosterone levels and suggest this as an important new mechanism linking obesity and hypertension. Figure 4 summarizes the pathophysiological roles of adipose aldosterone/MR activation in obesity-related hypertension.

Declaration of interest

The authors declare that there is no conflict of interest that could be perceived as prejudicing the impartiality of this review.

\section{Funding}

This work was supported by grants from the British Heart Foundation (BHF) (RG/13/7/30099; CH/12/429762) and the Canadian Institutes of Health Research (CIHR 44018). M F P was supported by a Wenner-Gren Foundation Fellowship. A W was supported by a Diabetes UK Sir George Alberti Research Training Fellowship.
(C) 2016 Society for Endocrinology Printed in Great Britain
Published by Bioscientifica Ltd 


\section{References}

Ahima RS, Prabakaran D, Mantzoros C, Qu D, Lowell B, Maratos-Flier E \& Flier JS 1996 Role of leptin in the neuroendocrine response to fasting. Nature 382 250-252. (doi:10.1038/382250a0)

Ahima RS 2008 Revisiting leptin's role in obesity and weight loss. Journal of Clinical Investigation 118 2380-2383. (doi:10.1172/JCI36284)

Amar L, Azizi M, Menard J, Peyrard S, Watson C \& Plouin PF 2010 Aldosterone synthase inhibition with LCI699: a proof-of-concept study in patients with primary aldosteronism. Hypertension $\mathbf{5 6}$ 831-838. (doi:10.1161/HYPERTENSIONAHA.110.157271)

Antoniades C, Antonopoulos AS, Tousoulis D \& Stefanadis C 2009 Adiponectin: from obesity to cardiovascular disease. Obesity Reviews 10 269-279. (doi:10.1111/j.1467-789X.2009.00571.x.)

Antonopoulos AS, Margaritis M, Coutinho P, Shirodaria C, Psarros C, Herdman L, Sanna F, De Silva R, Petrou M, Sayeed R, et al. 2015 Adiponectin as a link between type 2 diabetes and vascular NADPH oxidase activity in the human arterial wall: the regulatory role of perivascular adipose tissue. Diabetes 64 2207-2219. (doi:10.2337/ db14-1011)

Arakane F, King SR, Du Y, Kallen CB, Walsh LP, Watari H, Stocco DM \& Strauss JF 3rd 1997 Phosphorylation of steroidogenic acute regulatory protein (StAR) modulates its steroidogenic activity. Journal of Biological Chemistry 272 32656-32662. (doi:10.1074/ jbc.272.51.32656)

Armani A, Cinti F, Marzolla V, Morgan J, Cranston GA, Antelmi A, Carpinelli G, Canese R, Pagotto U, Quarta C, et al. 2014 Mineralocorticoid receptor antagonism induces browning of white adipose tissue through impairment of autophagy and prevents adipocyte dysfunction in high-fat-diet-fed mice. FASEB Journal 28 3745-3757. (doi:10.1096/fj.13-245415)

Balland E \& Cowley MA 2015 New insights in leptin resistance mechanisms in mice. Frontiers in Neuroendocrinology 39 59-65. (doi:10.1016/j.yfrne.2015.09.004)

Barter PJ, Caulfield M, Eriksson M, Grundy SM, Kastelein JJ, Komajda M, Lopez-Sendon J, Mosca L, Tardif JC, Waters DD, et al. 2007 Effects of torcetrapib in patients at high risk for coronary events. New England Journal of Medicine 357 2109-2122. (doi:10.1056/NEJMoa0706628)

Bassett MH, Zhang Y, White PC \& Rainey WE 2000 Regulation of human CYP11B2 and CYP11B1: comparing the role of the common CRE/Ad1 element. Endocrine Research 26 941-951. (doi:10.3109/07435800009048620)

Bassett MH, White PC \& Rainey WE 2004 The regulation of aldosterone synthase expression. Molecular and Cellular Endocrinology 217 67-74. (doi:10.1016/j.mce.2003.10.011)

Bentley-Lewis R, Adler GK, Perlstein T, Seely EW, Hopkins PN, Williams GH \& Garg R 2007 Body mass index predicts aldosterone production in normotensive adults on a high-salt diet. Journal of Clinical Endocrinology and Metabolism 92 4472-4475. (doi:10.1210/jc.2007-1088)

Bird IM, Hanley NA, Word RA, Mathis JM, McCarthy JL, Mason JI \& Rainey WE 1993 Human NCI-H295 adrenocortical carcinoma cells: a model for angiotensin-II-responsive aldosterone secretion. Endocrinology 133 1555-1561. (doi:10.1210/endo.133.4.8404594)

Bird IM, Mathis JM, Mason JI \& Rainey WE $1995 \mathrm{Ca}(2+)$-regulated expression of steroid hydroxylases in H295R human adrenocortical cells. Endocrinology 136 5677-5684. (doi:10.1210/ endo.136.12.7588323)

Bochud M, Nussberger J, Bovet P, Maillard MR, Elston RC, Paccaud F, Shamlaye C \& Burnier M 2006 Plasma aldosterone is independently associated with the metabolic syndrome. Hypertension 48 239-245. (doi:10.1161/01.HYP.0000231338.41548.fc)

Bollag WB 2014 Regulation of aldosterone synthesis and secretion. Comprehensive Physiology 4 1017-1055. (doi:10.1002/cphy.c130037)

Bomback AS, Muskala P, Bald E, Chwatko G \& Nowicki M 2009 Lowdose spironolactone, added to long-term ACE inhibitor therapy, reduces blood pressure and urinary albumin excretion in obese patients with hypertensive target organ damage. Clinical Nephrology 72 449-456. (doi:10.5414/CNP72449)

Brambilla G, Bombelli M, Seravalle G, Cifkova R, Laurent S, Narkiewicz K, Facchetti R, Redon J, Mancia G \& Grassi G 2013 Prevalence and clinical characteristics of patients with true resistant hypertension in central and Eastern Europe: data from the BP-CARE study. Journal of Hypertension 31 2018-2024. (doi:10.1097/HJH.0b013e328363823f)

Briones AM, Nguyen Dinh Cat A, Callera GE, Yogi A, Burger D, He Y, Corrêa JW, Gagnon AM, Gomez-Sanchez CE, Gomez-Sanchez EP, Sorisky A, et al. 2012 Adipocytes produce aldosterone through calcineurin-dependent signaling pathways: implications in diabetes mellitus-associated obesity and vascular dysfunction. Hypertension 59 1069-1078. (doi:10.1161/HYPERTENSIONAHA.111.190223)

Bruder-Nascimento T, da Silva MA \& Tostes RC 2014 The involvement of aldosterone on vascular insulin resistance: implications in obesity and type 2 diabetes. Diabetology and Metabolic Syndrome 690. (doi:10.1186/1758-5996-6-90)

Calhoun DA \& Sharma K 2010 The role of aldosteronism in causing obesity-related cardiovascular risk. Cardiology Clinics 28 517-527. (doi:10.1016/j.ccl.2010.04.001)

Calhoun DA, White WB, Krum H, Guo W, Bermann G, Trapani A, Lefkowitz MP \& Ménard J 2011 Effects of a novel aldosterone synthase inhibitor for treatment of primary hypertension: results of a randomized, double-blind, placebo- and active-controlled phase 2 trial. Circulation 124 1945-1955. (doi:10.1161/ CIRCULATIONAHA.111.029892)

Campbell JE, Peckett AJ, D'souza AM, Hawke TJ \& Riddell MC 2011 Adipogenic and lipolytic effects of chronic glucocorticoid exposure. American Journal of Physiology Cell Physiology 300 C198-209. (doi:10.1152/ajpcell.00045.2010)

Caprio M, Fève B, Claës A, Viengchareun S, Lombès M \& Zennaro MC 2007 Pivotal role of the mineralocorticoid receptor in corticosteroidinduced adipogenesis. FASEB Journal 21 2185-2194. (doi:10.1096/ fj.06-7970com)

Caprio M, Antelmi A, Chetrite G, Muscat A, Mammi C, Marzolla V, Fabbri A, Zennaro MC \& Fève B 2011 Antiadipogenic effects of the mineralocorticoid receptor antagonist drospirenone: potential implications for the treatment of metabolic syndrome. Endocrinology 152 113-125. (doi:10.1210/en.2010-0674)

Catena C, Lapenna R, Baroselli S, Nadalini E, Colussi G, Novello M, Favret G, Melis A, Cavarape A \& Sechi LA 2006 Insulin sensitivity in patients with primary aldosteronism: a follow-up study. Journal of Clinical Endocrinology and Metabolism 91 3457-3463. (doi:10.1210/ jc.2006-0736)

Chalupova L, Zakovska A \& Adamcova K 2013 Development of a novel enzyme-linked immunosorbent assay (ELISA) for measurement of serum CTRP1: a pilot study: measurement of serum CTRP1 in healthy donors and patients with metabolic syndrome. Clinical Biochemistry 46 73-78. (doi:10.1016/j.clinbiochem.2012.09.006)

Chen M, Wang Z, Zhan M, Liu R, Nie A, Wang J, Ning G \& Ma Q 2014 Adiponectin regulates ACTH secretion and the HPAA in an AMPKdependent manner in pituitary corticotroph cells. Molecular and Cellular Endocrinology 383 118-125. (doi:10.1016/j.mce.2013.12.007)

Crujeiras AB, Carreira MC, Cabia B, Andrade S, Amil M \& Casanueva FF 2015 Leptin resistance in obesity: An epigenetic landscape. Life Science 140 57-63. (doi:10.1016/j.lfs.2015.05.003)

Degawa-Yamauchi M, Moss KA, Bovenkerk JE, Shankar SS, Morrison CL, Lelliott CJ, Vidal-Puig A, Jones R \& Considine RV 2005 Regulation of adiponectin expression in human adipocytes: effects of adiposity, glucocorticoids, and tumor necrosis factor alpha. Obesity Research 13 662-669. (doi:10.1038/oby.2005.74)

Delcayre C \& Silvestre JS 1999 Aldosterone and the heart: towards a physiological function? Cardiovascular Research 43 7-12. (doi:10.1016/S0008-6363(99)00088-7)

Denner K, Rainey WE, Pezzi V, Bird IM, Bernhardt R \& Mathis JM 1996 Differential regulation of 11 beta-hydroxylase and aldosterone 
synthase in human adrenocortical H295R cells. Molecular and Cellular Endocrinology 121 87-91. (doi:10.1016/0303-7207(96)03853-1)

de Paula RB, da Silva AA \& Hall JE 2004 Aldosterone antagonism attenuates obesity-induced hypertension and glomerular hyperfiltration. Hypertension 43 41-47. (doi:10.1161/01. HYP.0000105624.68174.00)

Edwards CR, Stewart PM, Burt D, Brett L, McIntyre MA, Sutanto WS, de Kloet ER \& Monder C 1988 Localisation of 11 betahydroxysteroid dehydrogenase--tissue specific protector of the mineralocorticoid receptor. Lancet 2 986-989.

Ehrhart-Bornstein M, Lamounier-Zepter V, Schraven A, Langenbach J, Willenberg HS, Barthel A, Hauner H, McCann SM, Scherbaum WA \& Bornstein SR 2003 Human adipocytes secrete mineralocorticoidreleasing factors. PNAS 100 14211-14216. (doi:10.1073/ pnas.2336140100)

Felizola SJ, Maekawa T, Nakamura Y, Satoh F, Ono Y, Kikuchi K, Aritomi S, Ikeda K, Yoshimura M, Tojo K, et al. 2014 Voltage-gated calcium channels in the human adrenal and primary aldosteronism. Journal of Steroid Biochemistry and Molecular Biology 144 410-416. (doi:10.1016/j.jsbmb.2014.08.012)

Fiebeler A, Nussberger J, Shagdarsuren E, Rong S, Hilfenhaus G, Al-Saadi N, Dechend R, Wellner M, Meiners S, Maser-Gluth C, et al. 2005 Aldosterone synthase inhibitor ameliorates angiotensin II-induced organ damage. Circulation 111 3087-3094. (doi:10.1161/ CIRCULATIONAHA.104.521625)

Freitas Lima LC, Braga VA, do Socorro de França Silva M, Cruz JC, Sousa Santos SH, de Oliveira Monteiro MM \& Balarini CM 2015 Adipokines, diabetes and atherosclerosis: an inflammatory association. Frontiers in Physiology 6 304. (doi:10.3389/ fphys.2015.00304)

Friedman J 201420 years of leptin: leptin at 20: an overview. Journal of Endocrinology 223 T1-T8. (doi:10.1530/JOE-14-0405)

Fujimoto K, Honjo S, Tatsuoka H, Hamamoto Y, Kawasaki Y, Matsuoka A, Ikeda H, Wada Y, Sasano H \& Koshiyama H 2013 Primary aldosteronism associated with subclinical Cushing syndrome. Journal of Endocrinological Investigation 36 564-567. (doi:10.3275/8818)

Funder JW 2005 Mineralocorticoid receptors: distribution and activation. Heart Failure Review 10 15-22. (doi:10.1007/s10741-0052344-2)

Furukawa A, Miyatake A, Ohnishi T \& Ichikawa Y 1998 Steroidogenic acute regulatory protein (StAR) transcripts constitutively expressed in the adult rat central nervous system: colocalization of StAR, cytochrome P-450SCC (CYP XIA1), and 3beta-hydroxysteroid dehydrogenase in the rat brain. Journal of Neurochemistry 71 2231-2238.

Furukawa S, Fujita T, Shimabukuro M, Iwaki M, Yamada Y, Nakajima Y, Nakayama O, Makishima M, Matsuda M \& Shimomura I 2004 Increased oxidative stress in obesity and its impact on metabolic syndrome. Journal of Clinical Investigation 114 1752-1761. (doi:10.1172/JCI21625)

Gamliel-Lazarovich A, Raz-Pasteur A, Coleman R \& Keidar S 2013 The effects of aldosterone on diet-induced fatty liver formation in male C57BL/6 mice: comparison of adrenalectomy and mineralocorticoid receptor blocker. European Journal of Gastroenterology and Hepatology 25 1086-1092. (doi:10.1097/MEG.0b013e328360554a)

Garg R, Hurwitz S, Williams GH, Hopkins PN \& Adler GK 2010 Aldosterone production and insulin resistance in healthy adults. Journal of Clinical Endocrinology and Metabolism 95 1986-1990. (doi:10.1210/jc.2009-2521)

Gauthier MS, O'Brien EL, Bigornia S, Mott M, Cacicedo JM, Xu XJ, Gokce N, Apovian C \& Ruderman N 2011 Decreased AMP-activated protein kinase activity is associated with increased inflammation in visceral adipose tissue and with whole-body insulin resistance in morbidly obese humans. Biochemical and Biophysical Research Communications 404 382-387. (doi:10.1016/j.bbrc.2010.11.127)
Gilbert KC \& Brown NJ 2010 Aldosterone and inflammation. Current Opinion in Endocrinology, Diabetes Obesity 17 199-204.

Gomez-Sanchez CE, Zhou MY, Cozza EN, Morita H, Eddleman FC \& Gomez-Sanchez EP 1996 Corticosteroid synthesis in the central nervous system. Endocrine Research 22 463-470. (doi:10.1080/07435809609043732)

Gomez-Sanchez CE, Zhou MY, Cozza EN, Morita H, Foecking MF \& Gomez-Sanchez EP 1997 Aldosterone biosynthesis in the rat brain. Endocrinology 138 3369-3373. (doi:10.1210/endo.138.8.5326\#sthash. fA0p6z5p.dpuf)

Grim CE, Cowley AW Jr, Hamet P, Gaudet D, Kaldunski ML, Kotchen JM, Krishnaswami S, Pausova Z, Roman R, Tremblay J, et al. 2005 Hyperaldosteronism and hypertension: ethnic differences. Hypertension 45 766-772. (doi:10.1161/01.HYP.0000154364.00763.d5)

Guo C, Ricchiuti V, Lian BQ, Yao TM, Coutinho P, Romero JR, Li J, Williams GH \& Adler GK 2008 Mineralocorticoid receptor blockade reverses obesity-related changes in expression of adiponectin, peroxisome proliferator-activated receptor-gamma, and proinflammatory adipokines. Circulation 117 2253-2261. (doi:10.1161/CIRCULATIONAHA.107.748640)

Hall JE, do Carmo JM, da Silva AA, Wang Z \& Hall ME 2015 Obesity-induced hypertension: interaction of neurohumoral and renal mechanisms. Circulation Research 116 991-1006. (doi:10.1161/ CIRCRESAHA.116.305697)

Hargovan M \& Ferro A 2014 Aldosterone synthase inhibitors in hypertension: current status and future possibilities. JRSM Cardiovascular Disease 32048004014522440. (doi:10.1177/2048004014522440. eCollection 2014)

Hatakeyama H, Miyamori I, Takeda Y, Yamamoto H \& Mabuchi H 1996 The expression of steroidogenic enzyme genes in human vascular cells. Biochemistry and Molecular Biology International Journal 40 639-645.

Hattangady NG, Olala LO, Bollag WB \& Rainey WE 2012 Acute and chronic regulation of aldosterone production. Molecular and Cellular Endocrinology 350 151-162. (doi:10.1016/j.mce.2011.07.034)

Hirata A, Maeda N, Hiuge A, Hibuse T, Fujita K, Okada T, Kihara S, Funahashi T \& Shimomura I 2009 Blockade of mineralocorticoid receptor reverses adipocyte dysfunction and insulin resistance in obese mice. Cardiovascular Research 84 164-172. (doi:10.1093/cvr/ cvp191)

Hirata A, Maeda N, Nakatsuji H, Hiuge-Shimizu A, Okada T, Funahashi T \& Shimomura I 2012 Contribution of glucocorticoidmineralocorticoid receptor pathway on the obesity-related adipocyte dysfunction. Biochemical and Biophysical Research Communications 419 182-187. (doi:10.1016/j.bbrc.2012.01.139)

Hirsch A, Hahn D, Kempná P, Hofer G, Mullis PE, Nuoffer JM \& Flück CE 2012 Role of AMP-activated protein kinase on steroid hormone biosynthesis in adrenal NCI-H295R cells. PLOS ONE 7 e30956. (doi:10.1371/journal.pone.0030956)

Hosoya K, Minakuchi H, Wakino S, Fujimura K, Hasegawa K, Komatsu M, Yoshifuji A, Futatsugi K, Shinozuka K, Washida N, et al. 2015 Insulin resistance in chronic kidney disease is ameliorated by spironolactone in rats and humans. Kidney International 87 749-760. (doi:10.1038/ki.2014.348)

Hou N \& Luo JD 2011 Leptin and cardiovascular diseases. Clinical and Experimental Pharmacology and Physiology 38 905-913. (doi:10.1111/j.1440-1681.2011.05619.x)

Hu C, Rusin CG, Tan Z, Guagliardo NA \& Barrett PQ 2012 Zona glomerulosa cells of the mouse adrenal cortex are intrinsic electrical oscillators. Journal of Clinical Investigation 122 2046-2053. (doi:10.1172/JCI61996)

Huby AC, Antonova G, Groenendyk J, Gomez-Sanchez CE, Bollag WB, Filosa JA \& Belin de Chantemèle EJ 2015 Adipocyte-derived hormone leptin is a direct regulator of aldosterone secretion, which promotes endothelial dysfunction and cardiac fibrosis. http://jme.endocrinology-journals.org

DOI: 10.1530/JME-16-0025
(C) 2016 Society for Endocrinology Printed in Great Britain
Published by Bioscientifica Ltd 
Circulation 132 2134-2145. (doi:10.1161/

CIRCULATIONAHA.115.018226)

Hwang MH, Yoo JK, Luttrell M, Kim HK, Meade TH, English M, Segal MS \& Christou DD 2013 Mineralocorticoid receptors modulate vascular endothelial function in human obesity. Clinical Science $\mathbf{1 2 5}$ 513-520. (doi:10.1042/CS20130200)

Imayama I, Ulrich CM, Alfano CM, Wang C, Xiao L, Wener MH, Campbell KL, Duggan C, Foster-Schubert KE, Kong A, et al. 2012 Effects of a caloric restriction weight loss diet and exercise on inflammatory biomarkers in overweight/obese postmenopausal women: a randomized controlled trial. Cancer Research $\mathbf{7 2}$ 2314-2326. (doi:10.1158/0008-5472.CAN-11-3092)

Iwen KA, Senyaman O, Schwartz A, Drenckhan M, Meier B, Hadaschik D \& Klein J 2008 Melanocortin crosstalk with adipose functions: ACTH directly induces insulin resistance, promotes a pro-inflammatory adipokine profile and stimulates UCP-1 in adipocytes. Journal of Endocrinology 196 465-472. (doi:10.1677/JOE-07-0299)

Jaisser F \& Farman N 2016 Emerging roles of the mineralocorticoid receptor in pathology: toward new paradigms in clinical pharmacology. Pharmacological Reviews 68 49-75. (doi:10.1124/ pr.115.011106)

Jeon JH, Kim KY, Kim JH, Baek A, Cho H, Lee YH, Kim JW, Kim D, Han SH, Lim JS, et al. 2008 A novel adipokine CTRP1 stimulates aldosterone production. FASEB Journal 22 1502-1511. (doi:10.1096/ fj.07-9412com)

Johns DG, Duffy J, Fisher T, Hubbard BK \& Forrest MJ 2012 On- and offtarget pharmacology of torcetrapib: current understanding and implications for the structure activity relationships (SAR), discovery and development of cholesteryl ester-transfer protein (CETP) inhibitors. Drugs 72 491-507. (doi:10.2165/11599310-00000000000000)

Kargi AY \& Iacobellis G 2014 Adipose tissue and adrenal glands: novel pathophysiological mechanisms and clinical applications. International Journal of Endocrinology 2014614074. (doi:10.1155/2014/614074)

Karns AD, Bral JM, Hartman D, Peppard T \& Schumacher C 2013 Study of aldosterone synthase inhibition as an add-on therapy in resistant hypertension. Journal of Clinical Hypertension 15 186-192. (doi:10.1111/jch.12051)

Kidambi S, Kotchen JM, Grim CE, Raff H, Mao J, Singh RJ \& Kotchen TA 2007 Association of adrenal steroids with hypertension and the metabolic syndrome in blacks. Hypertension 49 704-711. Erratum in: Hypertension 49 e20.

Kim KY, Kim HY, Kim JH, Lee CH, Kim DH, Lee YH, Han SH, Lim JS, Cho DH, Lee MS, et al. 2006 Tumor necrosis factor-alpha and interleukin-1beta increases CTRP1 expression in adipose tissue. FEBS Letters 580 3953-3960. (doi:10.1016/j. febslet.2006.06.034)

Kontush A, Guérin M \& Chapman MJ 2008 Spotlight on HDL-raising therapies: insights from the torcetrapib trials. Nature Clinical Practice Cardiovascular Medicine 5 329-336. (doi:10.1038/ncpcardio1191)

Koska J, de Courten B, Wake DJ, Nair S, Walker BR, Bunt JC, Permana PA, Lindsay RS \& Tataranni PA 2006 11beta-hydroxysteroid dehydrogenase type 1 in adipose tissue and prospective changes in body weight and insulin resistance. Obesity 14 1515-1522. (doi:10.1038/oby.2006.175)

Kosmala W, Przewlocka-Kosmala M, Szczepanik-Osadnik H, Mysiak A \& Marwick TH 2013 Fibrosis and cardiac function in obesity: a randomised controlled trial of aldosterone blockade. Heart 99 320-326. (doi:10.1136/heartjnl-2012-303329)

Krug AW, Vleugels K, Schinner S, Lamounier-Zepter V, Ziegler CG, Bornstein SR \& Ehrhart-Bornstein M 2007 Human adipocytes induce an ERK1/2 MAP kinases-mediated upregulation of steroidogenic acute regulatory protein (StAR) and an angiotensin II-sensitization in human adrenocortical cells. International Journal of Obesity $\mathbf{3 1}$ 1605-1616. (doi:10.1038/sj.ijo.0803642)
Krug AW \& Ehrhart-Bornstein M 2008 Aldosterone and metabolic syndrome: is increased aldosterone in metabolic syndrome patients an additional risk factor? Hypertension 51 1252-1258. (doi:10.1161/ HYPERTENSIONAHA.107.109439)

Kushida A \& Tamura H 2009 Retinoic acids induce neurosteroid biosynthesis in human glial GI-1 Cells via the induction of steroidogenic genes. Journal of Biochemistry 146 917-923. (doi:10.1093/jb/mvp142)

Le Goascogne C, Robel P, Gouézou M, Sananès N, Baulieu EE \& Waterman M 1987 Neurosteroids: cytochrome P-450scc in rat brain. Science 237 1212-1215. (doi:10.1126/science.3306919)

Li J, Feltzer RE, Dawson KL, Hudson EA \& Clark BJ 2003 Janus kinase 2 and calcium are required for angiotensin II-dependent activation of steroidogenic acute regulatory protein transcription in H295R human adrenocortical cells. Journal of Biological Chemistry 278 52355-52362. (doi:10.1074/jbc.M305232200)

Li P, Sun F, Cao HM, Ma QY, Pan CM, Ma JH, Zhang XN, Jiang H, Song HD \& Chen MD 2009 Expression of adiponectin receptors in mouse adrenal glands and the adrenocortical Y-1 cell line: adiponectin regulates steroidogenesis. Biochemical and Biophysical Research Communications 390 1208-1213. (doi:10.1016/j. bbrc.2009.10.122)

Lin D, Sugawara T, Strauss JF 3rd, Clark BJ, Stocco DM, Saenger P, Rogol A \& Miller WL 1995 Role of steroidogenic acute regulatory protein in adrenal and gonadal steroidogenesis. Science 267 1828-1831. (doi:10.1126/science.7892608)

Luo P, Dematteo A, Wang Z, Zhu L, Wang A, Kim HS, Pozzi A, Stafford JM \& Luther JM 2013 Aldosterone deficiency prevents highfat-feeding-induced hyperglycaemia and adipocyte dysfunction in mice. Diabetologia 56 901-910. (doi:10.1007/s00125-012-2814-8)

Mantzoros CS 1999 The role of leptin in human obesity and disease: a review of current evidence. Annals of Internal Medicine 130 671-680. (doi:10.7326/0003-4819-130-8-199904200-00014)

Marcinko K \& Steinberg GR 2014 The role of AMPK in controlling metabolism and mitochondrial biogenesis during exercise. Experimental Physiology 99 1581-1585. (doi:10.1113/ expphysiol.2014.082255)

Marzolla V, Armani A, Zennaro MC, Cinti F, Mammi C, Fabbri A, Rosano GM \& Caprio M 2012 The role of the mineralocorticoid receptor in adipocyte biology and fat metabolism. Molecular Cellular and Endocrinology 350 281-288. (doi:10.1016/j.mce.2011.09.011)

Matsumoto S, Takebayashi K \& Aso Y 2006 The effect of spironolactone on circulating adipocytokines in patients with type 2 diabetes mellitus complicated by diabetic nephropathy. Metabolism $\mathbf{5 5}$ 1645-1652. (doi:10.1016/j.metabol.2006.07.025)

McCurley A, Pires PW, Bender SB, Aronovitz M, Zhao MJ, Metzger D, Chambon P, Hill MA, Dorrance AM, Mendelsohn ME, et al. 2012 Direct regulation of blood pressure by smooth muscle cell mineralocorticoid receptors. Nature Medicine 8 1429-1433. (doi:10.1038/nm.2891)

Ménard J \& Pascoe L 2006 Can the dextroenantiomer of the aromatase inhibitor fadrozole be useful for clinical investigation of aldosteronesynthase inhibition? Journal of Hypertension 24 993-997. (doi:10.1097/01.hjh.0000226183.98439.b3)

Morton NM, Paterson JM, Masuzaki H, Holmes MC, Staels B, Fievet C, Walker BR, Flier JS, Mullins JJ \& Seckl JR 2004 Novel adipose tissue-mediated resistance to diet-induced visceral obesity in 11 beta-hydroxysteroid dehydrogenase type 1-deficient mice. Diabetes 53 931-938. (doi:10.2337/diabetes.53.4.931)

Nagase M, Yoshida S, Shibata S, Nagase T, Gotoda T, Ando K \& Fujita T 2006 Enhanced aldosterone signaling in the early nephropathy of rats with metabolic syndrome: possible contribution of fat-derived factors. Journal of the American Society of Nephrology 17 3438-3446. (doi:10.1681/ASN.2006080944)

Nguyen Dinh Cat A, Griol-Charhbili V, Loufrani L, Labat C, Benjamin L, Farman N, Lacolley P, Henrion D \& Jaisser F 2010 The endothelial

Published by Bioscientifica Ltd. 
mineralocorticoid receptor regulates vasoconstrictor tone and blood pressure. FASEB Journal 24 2454-2463. (doi:10.1096/fj.09-147926)

Nguyen Dinh Cat A, Briones AM, Callera GE, Yogi A, He Y, Montezano AC \& Touyz RM 2011 Adipocyte-derived factors regulate vascular smooth muscle cells through mineralocorticoid and glucocorticoid receptors. Hypertension 58 479-488. (doi:10.1161/ HYPERTENSIONAHA.110.168872)

Nguyen Dinh Cat A \& Jaisser F 2012 Extrarenal effects of aldosterone. Current Opinion in Nephrology and Hypertension 21 147-156. (doi:10.1097/MNH.0b013e32834fb25b)

Nguyen Dinh Cat A, Antunes TT, Callera GE, Sanchez A, Tsiropoulou S, Dulak-Lis MG, Anagnostopoulou A, He Y, Montezano AC, Jaisser F \& Touyz RM 2016 Adipocytes-specific mineralocorticoid receptors overexpression in mice is associated with metabolic syndrome and vascular dysfunction: role of redox-sensitive PKG-1 and Rho kinase. Diabetes [in press]. (doi:10.2337/db15-1627)

Nigro E, Scudiero O, Monaco ML, Palmieri A, Mazzarella G, Costagliola C, Bianco A \& Daniele A 2014 New insight into adiponectin role in obesity and obesity-related diseases. Biomed Research International 2014 658913. (doi:10.1155/2014/658913)

Northcott CA, Fink GD, Garver H, Haywood JR, Laimon-Thomson EL, McClain JL, Pires PW, Rainey WE, Rigsby CS \& Dorrance AM 2012 The development of hypertension and hyperaldosteronism in a rodent model of life-long obesity. Endocrinology 153 1764-1773. (doi:10.1210/en.2011-1176)

O’Keefe JH, Abuissa H \& Pitt B 2008 Eplerenone improves prognosis in postmyocardial infarction diabetic patients with heart failure: results from EPHESUS. Diabetes, Obesity and Metabolism 10 492-497. (doi:10.1111/j.1463-1326.2007.00730.x)

Pan H, Guo J \& Su Z 2014 Advances in understanding the interrelations between leptin resistance and obesity. Physiology and Behavior 130 157-169. (doi:10.1016/j.physbeh.2014.04.003)

Park HK \& Ahima RS 2014 Leptin signaling. F1000Prime Reports 673. (doi:10.12703/P6-73. eCollection 2014)

Park HK \& Ahima RS 2015 Physiology of leptin: energy homeostasis, neuroendocrine function and metabolism. Metabolism 6 24-34. (doi:10.1016/j.metabol.2014.08.004)

Paschke L, Zemleduch T, Rucinski M, Ziolkowska A, Szyszka M \& Malendowicz LK 2010 Adiponectin and adiponectin receptor system in the rat adrenal gland: ontogenetic and physiologic regulation, and its involvement in regulating adrenocortical growth and steroidogenesis. Peptides 31 1715-1724. (doi:10.1016/j.peptides.2010.06.007)

Peterson JM, Aja S, Wei Z \& Wong GW 2012 CTRP1 protein enhances fatty acid oxidation via AMP-activated protein kinase (AMPK) activation and acetyl-CoA carboxylase (ACC) inhibition. Journal of Biological Chemistry 287 1576-1587. (doi:10.1074/jbc.M111.27833)

Pitt B, Zannad F, Remme WJ, Cody R, Castaigne A, Perez A, Palensky J \& Wittes J 1999 The effect of spironolactone on morbidity and mortality in patients with severe heart failure. Randomized Aldactone Evaluation Study Investigators. New England Journal of Medicine 341 709-717. (doi:10.1056/NEJM199909023411001)

Pitt B, Remme W, Zannad F, Neaton J, Martinez F, Roniker B, Bittman R, Hurley S, Kleiman J \& Gatlin M 2003 Eplerenone post-acute myocardial infarction heart failure efficacy and survival study investigators. Eplerenone, a selective aldosterone blocker, in patients with left ventricular dysfunction after myocardial infarction. New England Journal of Medicine 348 1309-1321. Erratum in: New England Journal of Medicine 348 2271. (doi:10.1056/NEJMoa030207)

Preiss D, van Veldhuisen DJ, Sattar N, Krum H, Swedberg K, Shi H, Vincent J, Pocock SJ, Pitt B, Zannad F, et al. 2012 Eplerenone and new-onset diabetes in patients with mild heart failure: results from the Eplerenone in Mild Patients Hospitalization and Survival Study in Heart Failure (EMPHASIS-HF). European Journal of Heart Failure $\mathbf{1 4}$ 909-915. (doi:10.1093/eurjhf/hfs067)

Rainey WE, Bird IM, Sawetawan C, Hanley NA, McCarthy JL, McGee EA, Wester R \& Mason JI 1993 Regulation of human adrenal carcinoma cell (NCI-H295) production of C19 steroids. Journal of Clinical Endocrinology and Metabolism 77 731-737. (doi:10.1210/ jcem.77.3.8396576)

Rajamohan SB, Raghuraman G, Prabhakar NR \& Kumar GK 2012 NADPH oxidase-derived $\mathrm{H}(2) \mathrm{O}(2)$ contributes to angiotensin II-induced aldosterone synthesis in human and rat adrenal cortical cells. Antioxidants and Redox Signaling 17 445-459. (doi:10.1089/ ars.2011.4176)

Rios FJ, Neves KB, Nguyen Dinh Cat A, Even S, Palacios R, Montezano AC \& Touyz RM 2015 Cholesteryl ester-transfer protein inhibitors stimulate aldosterone biosynthesis in adipocytes through Nox-dependent processes. Journal of Pharmacology and Experimental Therapeutics 353 27-34. (doi:10.1124/jpet.114.221002)

Romero DG, Plonczynski M, Vergara GR, Gomez-Sanchez EP \& GomezSanchez CE 2004 Angiotensin II early regulated genes in H295R human adrenocortical cells. Physiological Genomics 19 106-116. (doi:10.1152/physiolgenomics.00097.2004)

Rossi GP, Sticchi D, Giuliani L, Bernante P, Zavattiero S, Pessina AC \& Nussdorfer GG 2006 Adiponectin receptor expression in the human adrenal cortex and aldosterone-producing adenomas. International Journal of Molecular Medicine 17 975-980. (doi:10.3892/ijmm.17.6.975)

Rossi GP, Belfiore A, Bernini G, Fabris B, Caridi G, Ferri C, Giacchetti G, Letizia C, Maccario M, Mannelli M, et al. 2008 Primary aldosteronism prevalence in hypertension study investigators. Body mass index predicts plasma aldosterone concentrations in overweight-obese primary hypertensive patients. Journal of Clinical Endocrinology and Metabolism 93 2566-2571. (doi:10.1210/jc.2008-0251)

Rossignol P, Ménard J, Fay R, Gustafsson F, Pitt B \& Zannad F 2011 Eplerenone survival benefits in heart failure patients post-myocardial infarction are independent from its diuretic and potassium-sparing effects. Insights from an EPHESUS (Eplerenone Post-Acute Myocardial Infarction Heart Failure Efficacy and Survival Study) substudy. Journal of the American College of Cardiology 58 1958-1966. (doi:10.1016/j.jacc.2011.04.049)

Sainte-Marie Y, Nguyen Dinh Cat A, Perrier R, Mangin L, Soukaseum C, Peuchmaur M, Tronche F, Farman N, Escoubet B, Benitah JP, et al. 2007 Conditional glucocorticoid receptor expression in the heart induces atrio-ventricular block. FASEB Journal 21 3133-3141. (doi:10.1096/fj.07-8357com)

Sáinz N, Barrenetxe J, Moreno-Aliaga MJ \& Martínez JA 2015 Leptin resistance and diet-induced obesity: central and peripheral actions of leptin. Metabolism 64 35-46. (doi:10.1016/j.metabol.2014.10.015)

Schäfer N, Lohmann C, Winnik S, van Tits LJ, Miranda MX, Vergopoulos A, Ruschitzka F, Nussberger J, Berger S, Lüscher TF, et al. 2013 Endothelial mineralocorticoid receptor activation mediates endothelial dysfunction in diet-induced obesity. European Heart Journal 34 3515-3524. (doi:10.1093/eurheartj/eht095)

Schinner S, Willenberg HS, Krause D, Schott M, Lamounier-Zepter V, Krug AW, Ehrhart-Bornstein M, Bornstein SR \& Scherbaum WA 2007 Adipocyte-derived products induce the transcription of the StAR promoter and stimulate aldosterone and cortisol secretion from adrenocortical cells through the Wnt-signaling pathway. International Journal of Obesity 31 864-870. (doi:10.1038/sj.ijo.0803508)

Schwartz GG, Olsson AG, Abt M, Ballantyne CM, Barter PJ, Brumm J, Chaitman BR, Holme IM, Kallend D, Leiter LA, et al. 2012 Effects of dalcetrapib in patients with a recent acute coronary syndrome. New England Journal of Medicine 367 2089-2099. (doi:10.1056/ NEJMoa1206797)

Shibata R, Murohara T \& Ouchi N 2012 Protective role of adiponectin in cardiovascular disease. Current Medicinal Chemistry 19 5459-5466. (doi:10.2174/092986712803833164)

Silvestre JS, Robert V, Heymes C, Aupetit-Faisant B, Mouas C, Moalic JM, Swynghedauw B \& Delcayre C 1998 Myocardial production of aldosterone and corticosterone in the rat. Physiological regulation. Journal of Biological Chemistry 273 4883-4891. (doi:10.1074/ jbc.273.9.4883)

Published by Bioscientifica Ltd. 
Sowers JR 2008 Endocrine functions of adipose tissue: focus on adiponectin. Clinical Cornerstone 9 32-38. (doi:10.1016/S10983597(08)60026-5)

Sowers JR, Whaley-Connell A \& Epstein M 2009 Narrative review: the emerging clinical implications of the role of aldosterone in the metabolic syndrome and resistant hypertension. Annals of Internal Medicine 150 776-783. (doi:10.7326/0003-4819-150-11-20090602000005)

Späth M, Korovkin S, Antke C, Anlauf M \& Willenberg HS 2011 Aldosterone- and cortisol-co-secreting adrenal tumors: the lost subtype of primary aldosteronism. European Journal of Endocrinology 164 447-55. (doi:10.1530/EJE-10-1070)

Stimson RH \& Walker BR 2007 Glucocorticoids and 11betahydroxysteroid dehydrogenase type 1 in obesity and the metabolic syndrome. Minerva Endocrinologica 32 141-159.

Strömstedt M \& Waterman MR 1995 Messenger RNAs encoding steroidogenic enzymes are expressed in rodent brain. Brain Research Molecular Brain Research 34 75-88. (doi:10.1016/0169-328X(95)00140-N)

Sweeney G 2010 Cardiovascular effects of leptin. Nature Reviews Cardiology 7 22-29. (doi:10.1038/nrcardio.2009.224)

Takeda R, Hatakeyama H, Takeda Y, Iki K, Miyamori I, Sheng WP, Yamamoto H \& Blair IA 1995 Aldosterone biosynthesis and action in vascular cells. Steroids 60 120-124. Erratum in: Steroids 60540. (doi:10.1210/jcem.81.8.8768832)

Takeda Y, Miyamori I, Yoneda T, Iki K, Hatakeyama H, Blair IA, Hsieh FY \& Takeda R 1995 Production of aldosterone in isolated rat blood vessels. Hypertension 25 170-173. (doi:10.1161/01.HYP.25.2.170)

Takeda Y, Miyamori I, Yoneda T, Furukawa K, Hatakeyama H, Inaba S, Ito Y, Takeda R \& Mabuchi H 1996 Effect of adrenocorticotropin stimulation on the synthesis of 19-noraldosterone in man. Journal of Clinical Endocrinology and Metabolism 81 1852-1855. (doi:10.1210/ jcem.81.5.8626846)

Thatcher S, Yiannikouris F, Gupte M \& Cassis L 2009 The adipose reninangiotensin system: role in cardiovascular disease. Molecular and Cellular Endocrinology 302 111-117. (doi:10.1016/j.mce.2009.01.019)

Tirosh A, Garg R, Adler GK 2010 Mineralocorticoid receptor antagonists and the metabolic syndrome. Current Hypertension Reports 12 252-257. (doi:10.1007/s11906-010-0126-2)

Tokuyama H, Wakino S, Hara Y, Washida N, Fujimura K, Hosoya K, Yoshioka K, Hasegawa K, Minakuchi H, Homma K, et al. 2012 Role of mineralocorticoid receptor/Rho/Rho-kinase pathway in obesityrelated renal injury. International Journal of Obesity 36 1062-1071. (doi:10.1038/ijo.2011.232)

Urbanet R, Nguyen Dinh Cat A, Feraco A, Venteclef N, El Mogrhabi S, Sierra-Ramos C, Alvarez de la Rosa D, Adler GK, Quilliot D, Rossignol P, et al. 2015 Adipocyte mineralocorticoid receptor activation leads to metabolic syndrome and induction of prostaglandin D2 synthase. Hypertension 66 149-157. (doi:10.1161/ HYPERTENSIONAHA.114.04981)
Vogt B, Bochud M \& Burnier M 2007 The association of aldosterone with obesity-related hypertension and the metabolic syndrome. Seminars in Nephrology 27 529-537. (doi:10.1016/j. semnephrol.2007.07.009)

Wada T, Ohshima S, Fujisawa E, Koya D, Tsuneki H \& Sasaoka T 2009 Aldosterone inhibits insulin-induced glucose uptake by degradation of insulin receptor substrate (IRS) 1 and IRS2 via a reactive oxygen species-mediated pathway in 3T3-L1 adipocytes. Endocrinology 150 1662-1669. (doi:10.1210/en.2008-1018)

Wada N, Hirako S, Takenoya F, Kageyama H, Okabe M \& Shioda S 2014 Leptin and its receptors. Journal of Chemical Neuroanatomy 61-62 191-199. (doi:10.1016/j.jchemneu.2014.09.002)

Wong GW, Krawczyk SA, Kitidis-Mitrokostas C, Revett T, Gimeno R \& Lodish HF 2008 Molecular, biochemical and functional characterizations of C1q/TNF family members: adipose-tissueselective expression patterns, regulation by PPAR-gamma agonist, cysteine-mediated oligomerizations, combinatorial associations and metabolic functions. Biochemical Journal 416 161-177. (doi:10.1042/ BJ20081240)

Wu P, Guo Z, Zhang Y, Liu Y, Liang X, Zhang R, Lai W, Takeda Y, Isamu M \& Takeda R 1998 Aldosterone overproduction and CYP11B2 mRNA overexpression in vessels of spontaneously hypertensive rats. Hormone Research 50 28-31. (doi:10.1159/000023197)

Xin Y, Lyu X, Wang C, Fu Y, Zhang S, Tian C, Li Q \& Zhang D 2014 Elevated circulating levels of CTRP1, a novel adipokine, in diabetic patients. Endocrine Journal 61 841-847. (doi:10.1507/endocrj.EJ14-0016)

Yamashiro T, Kuge H, Zhang J \& Honke K 2010 Calcineurin mediates the angiotensin II-induced aldosterone synthesis in the adrenal glands by up-regulation of transcription of the CYP11B2 gene. Journal of Biochemistry 148 115-123. (doi:10.1093/jb/mvq037)

Yang R \& Barouch LA 2007 Leptin signaling and obesity: cardiovascular consequences. Circulation Research 101 545-559. (doi:10.1161/ CIRCRESAHA.107.156596)

Zannad F, McMurray JJ, Krum H, van Veldhuisen DJ, Swedberg K, Shi H, Vincent J, Pocock SJ, Pitt B \& EMPHASIS-HF Study Group 2011 Eplerenone in patients with systolic heart failure and mild symptoms. New England Journal of Medicine 364 11-21. (doi:10.1056/ NEJMoa1009492)

Zennaro MC, Caprio M \& Fève B 2009 Mineralocorticoid receptors in the metabolic syndrome. Trends in Endocrinology and Metabolism 20 444-451. (doi:10.1016/j.tem.2009.05.006)

Zulian E, Sartorato P, Benedini S, Baro G, Armanini D, Mantero F \& Scaroni C 2005 Spironolactone in the treatment of polycystic ovary syndrome: effects on clinical features, insulin sensitivity and lipid profile. Journal of Endocrinology Investigation 28 49-53. (doi:10.1007/ BF03345529)

Zwain IH \& Yen SS 1999 Neurosteroidogenesis in astrocytes, oligodendrocytes, and neurons of cerebral cortex of rat brain. Endocrinology 140 3843-3852.

Received in final form 29 April 2016

Accepted 9 May 2016 http://jme.endocrinology-journals.org

DOI: 10.1530/JME-16-0025
() 2016 Society for Endocrinology Printed in Great Britain
Published by Bioscientifica Ltd. 